\title{
PENINGKATAN SOFTSKILL ICT GURU MELALUI PEMBUATAN ANIMASI BAGI GURU SEKOLAH DASAR
}

\author{
Muhammad Ikhsan ${ }^{1}$ \\ Fakultas Keguruan dan Ilmu Pendidikan \\ Universitas Widya Gama Mahakam Samarinda \\ Email: ichsan@uwgm.ac.id
}

\begin{abstract}
ABSTRAK
Kegiatan pengabdian masyarakat dilaksanakan bertujuan untuk meningkatkan kemampuan softskill guru dalam mengembangkan pembelajaran berbasis teknologi informasi dan komunikasi khususnya dalam pembuatan materi ajar menggunakan powerpoint. Kegiatan ini dilaksanakan atas dasar kebutuhan guru dalam pembelajaran online selama masa pandemic covid-19, sehingga dibutuhkan kemampuan dalam melaksanakan, merancang kegiatan pembelajaran digital berbasis teknologi informasi. Metode pelaksanaan pengabdian masyarakat ini menggunakan metode demonstrasi dan project bahan ajar. Berdasarkan hasil wawancara yang dilakukan terdapat peningkatan kemampuan dalam mengembangkan pembelajaran digital dilihat dari karya yang diciptakan oleh guru berupa animasi menggunakan powerpoint. Berdasarkan kegiatan pengabdian yang telah dilaksanakan dapat disimpulkan Pelatihan ini memberikan beberapa materi yang mendukung pembelajaran berbasis digital atau online dengan memberikan pengetahuan pemanfaatan powerpoint untuk animasi sehingga menjadi bahan belajar yang interaktif
\end{abstract}

Kata kunci : pembelajaran digital, bahan interaktif

\section{PENDAHULUAN}

Pandemi Covid-19 menuntut proses pembelajaran berlangsung secara daring. Hal ini menuntut seorang guru memiliki kemampuan dalam teknologi informasi dan komunikasi khususnya sebagai penunjang proses belajar mengajar secara online. Perubahan sistem pembelajaran luring menjadi sistem pembelajaran online terjadi secara bersama di Indonesia mulai dari perkotaan hingga ke pelosok desa. Beberapa sekolah secara bersama menyiapkan keterampilan dalam kemampuan teknologi informasi dalam proses pembelajaran.

Guru sebagai ujung tombak dalam suksesnya tujuan pembelajaran banyak yang belum siap dengan fenomena ini. Sehingga guru mengalami kesulitan dalam proses pembelajaran secara daring. Salah satu upaya yang dapat dilakukan adalah meningkatkan kemampuan guru pada kemampuan teknologi informasi dan komunikasi, sehingga pembelajaran online yang dilakukan sesuai dengan tujuan Pendidikan nasional. Upaya yang dilakukan untuk meningkatkan kemampuan teknologi, informasi dan komunikasi diantaranya dalam menggunakan aplikasi aplikasi pembelajaran online diantaranya 
zoom, google classroom, Google Form, dan pembuataan media pembelajaran berupa animasi dan video.

Salah satu cara yang dapat dilakukan sebagai tuntutan adalah mengubah system pembelajaran konvensional menjadi system pembelajaran yang efektif dan efisien melalui peningkatan kemampuan guru. (Zedadra et al., 2019) Hasil pengabdian serupa juga dilakukan dan mendapatkan hasil yang sangat positif dan guru sangat antusias mengikuti kegiatan pendampingan dalam peningkatan softskill ICT guru. (Sataloff et al., n.d.) peningkatan kemampuan guru dalam penggunaan dan pengolahan menggunakan powerpoint dilakukan dengan baik sehingga dapat menambah kemampuan dalam proses belajar mengajar .Kegiatan pengabdian masyarakat ini bertujuan untuk meningkatkan softskill guru dalam melakasanakan proses pembelajaran daring di sekolah dasar.

\section{METODE}

Ada tiga metode yang dilaksanakan dalam kegiatan pengabdian ini diantaranya yaitu metode presentasi, metode metode demonstrasi dan metode project. Pada tahapan metode presentasi kami dari tim pengabdian masyarakat datang kesekolah untuk memberikan pelatihan dan materi yang berkaitan dengan peningkatan keterampilan teknologi informasi dan komunikasi. Pada tahapan demonstrasi tim pengabdian masyarakat mendampingi guru untuk menggunakan aplikasi aplikasi yang berhubungan dengan proses pembelajaran dikelas dan cara pembuatan konten animasi menggunakan powerpoint. Pada tahapan project peserta guru diminta untuk membuat animasi menggunakan Microsoft powerpoint baik itu untuk tujuan presentasi dan game dikelas.

\section{HASIL DAN PEMBAHASAN}

Salah satu ujung tombak tercapainya tujuan pembelajaran adalah guru. Namun, tanpa dukungan pengembangan keterampilan dalam bidang teknologi informasi dan komunikasi pembelajaran proses pembelajaran secara daring tidak berjalan sesuai harapan. Dukungan juga didapat dari sekolah dalam bentuk sarana dan prasarana sehingga menunjang proses pembelajaran online.

Pemanfaatan teknologi informasi dan komunikasi pada guru masih perlu ditingkatkan untuk mendukung pembelajaran secara online sehingga perlu dukungan dari berbagai pihak untuk mendukung pembelajaran yang dilaksanakan secara online. Pelatihan ini memberikan beberapa materi yang mendukung pembelajaran online diantaranya penggunaan Microsoft 
power point. Software Microsoft power point umumnya digunakan untuk mempresentasikan, dalam pelatihan ini Microsoft power point tidak hanya digunakan untuk presentasi , namun juga bisa digunakan untuk membuat konten animasi sebagai media pembelajaran secara online. Microsoft power point sebagai sumber merancang animasi dikarenakan power point sudah sangat familiar digunakan oleh guru, sehingga hanya mengembangkan beberapa fitur lainnya.

Pelaksanaan pengabdian masyarakat dalam mengembangkan kemampuan guru menggunakan powerpoint juga dilakukan dan mendapat respon positif dari peserta sehingga guru mampu mengembangkan content pembelajaran guna mendukung pembelajaran daring. (Sataloff et al., n.d.) Adapun pengembangan kemampuan menggunakan powerpoint yang akan dicapai adalah game buka pembahasan, game ini dapat dibuat secara sederhana oleh guru dan langsung dipraktikan Bersama. Hal ini membuat proses pembelajaran online menjadi menarik, karena dapat digunakan secara interaktif oleh guru dan peserta didik.

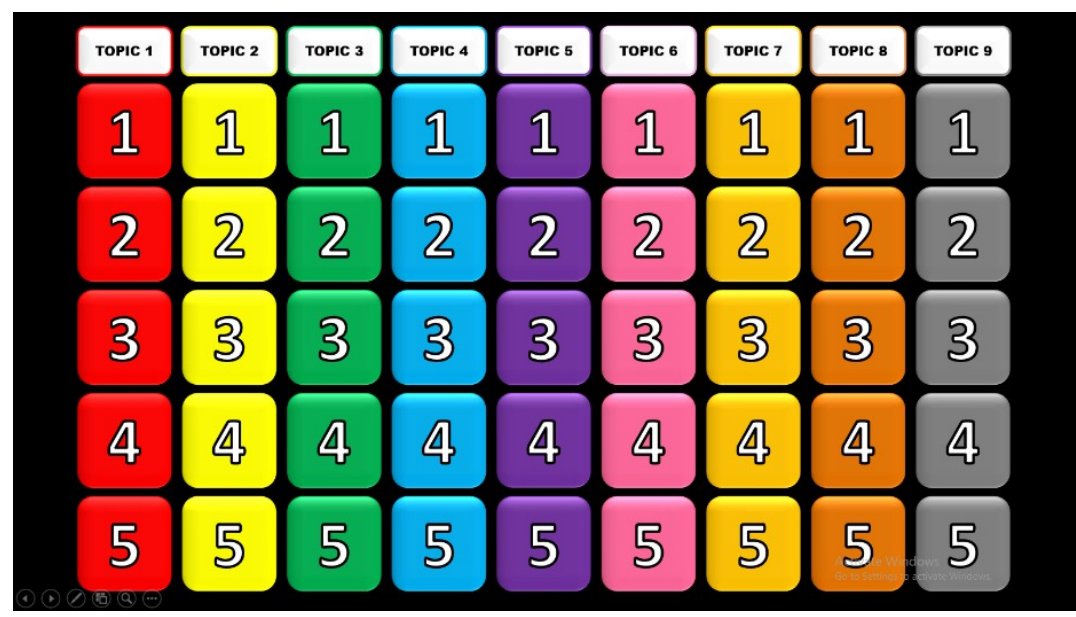

Gambar 1. Contoh Game Powerpoint

Pada pengembangan kemampuan Microsoft powerpoint juga digunakan untuk membuat teka teki. Pada bagian ini guru sebagai peserta dituntut untuk mampu membuat teka-teki secara interaktif guna pelaksanaan proses pembelajaran secara online. 


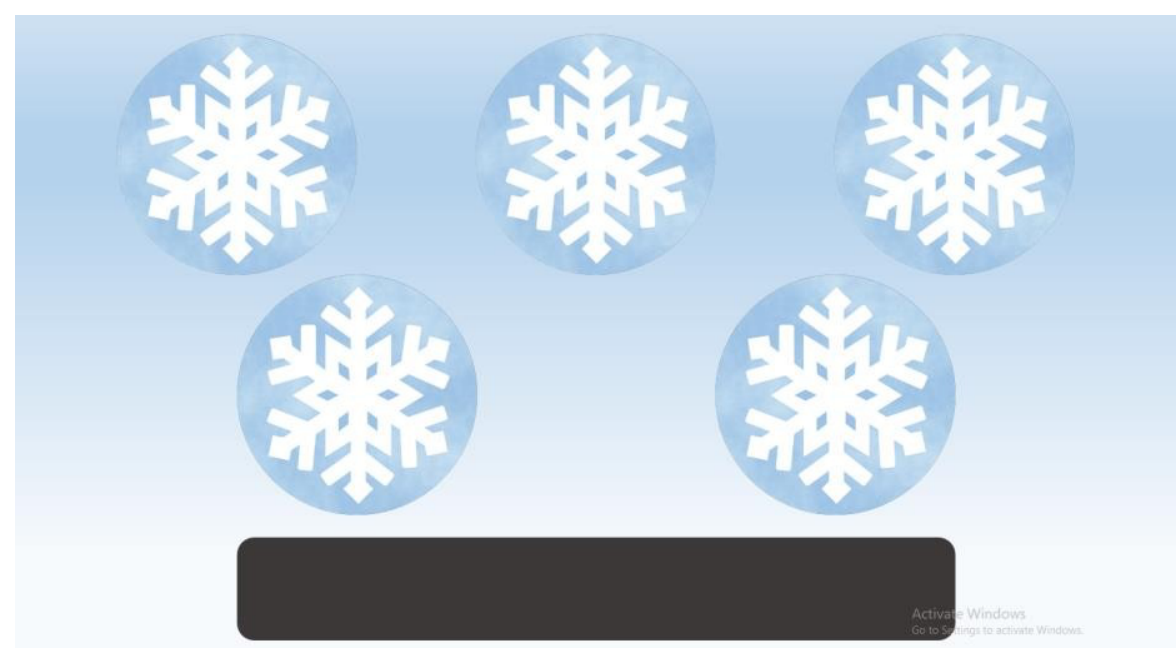

Kemampuan lainnya yang dikembangkan adalah membuat konten Tebak benar-salah, ini membuat pembelajaran online tidak monoton sehingga pembelajaran menjadi lebih kreatif dan interaktif.

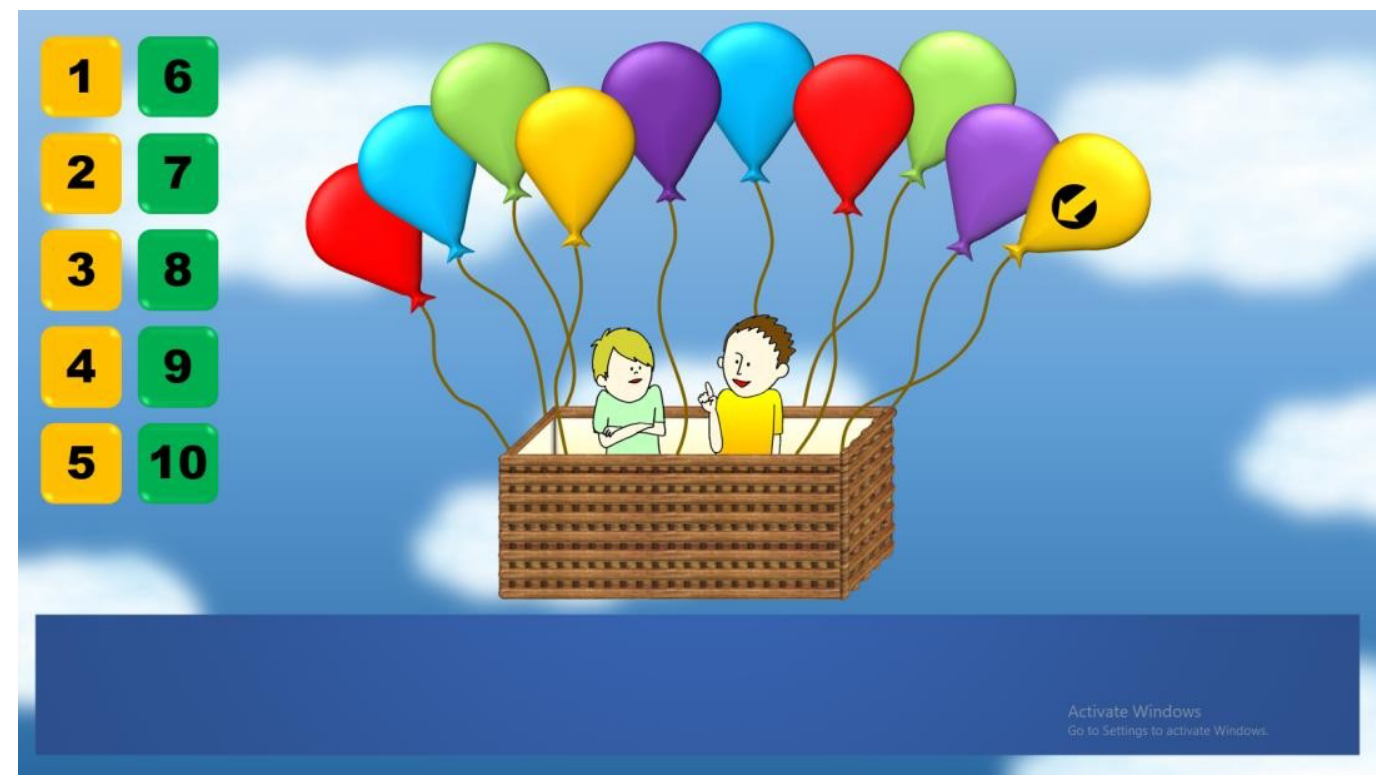

Setelah kegiatan pelatihan dilaksanakan dilakukan wawancara pada peserta pelatihan yang bertujuan untuk melihat peningkatan keterampilan yang dimiliki. Berdasarkan hasil wawancara yang dilakukan oleh peserta terdapat peningkatan kemampuan softskill dalam 
teknologi informasi yaitu penggunaan powerpoint sebagai bahan ajar animasi dan interaktif. Hal ini mendapat respon positif karena peserta sudah familiar terhadap powerpoint hanya saja belum memahami fitur yang tersedia untuk animasi dan bahan ajar interaktif.

\section{KESIMPULAN}

Berdasarkan hasil pelaksanaan kegiatan pengabdian masyarakat yang dilakukan dapat disimpulkan sebagai berikut :

a. Pelatihan ini memberikan beberapa materi yang mendukung pembelajaran berbasis digital atau online dengan memberikan pengetahuan pemanfaatan powerpoint untuk animasi sehingga menjadi bahan belajar yang interaktif

b. Materi yang diberikan dapat diterima dengan baik oleh peserta pelatihan

\section{DAFTAR PUSTAKA}

Anderson, Ronald A. 1994. Pemilihan dan Pengembangan Media untuk Pembelajaran, terjemahan oleh Yusufhadi Miarso, dkk. Jakarta: PT. Raja Grafindo Persada.

Arsyad, A. 2002. Media Pembelajaran. PT Raja Grafindo Persada: Jakarta. Miarso, Yusufhadi. 2004. Menyemai Benih Teknologi Pendidikan. Jakarta: Prenada Media.

Purnomo. 1996. Strategi Pengajaran. Yogyakarta: Universitas Sanata Dharma.

Joyce, Bruce, Marsha, Weil, and Beverly Showers. (1992). Models of Teaching. Boston: Allyn and Bacon.

Budiman, Haris. "Peran Teknologi Informasi Dan Komunikasi Dalam Pendidikan.” Al-Tadzkiyyah: Jurnal Pendidikan Islam 8, no. 1 (2017). https://doi.org/10.24042/atjpi.v 8i1.2095. 